\title{
Evaluation of natural foci of Panstrongylus megistus in a forest fragment in Porto Alegre, State of Rio Grande do Sul, Brazil
}

\author{
José Eloy dos Santos Jr ${ }^{[1]}$, Mariana Gubert Viola ${ }^{[2]}$, Elias Seixas Lorosa ${ }^{[3]}$, \\ Evandro Marques de Menezes Machado ${ }^{[5]}$, Antonio Leite Ruas Neto ${ }^{[5]}$ \\ and Elio Corseuil[6]
}

[1]. Laboratório de Triatomíneos e Epidemiologia da Doença de Chagas, Centro de Pesquisas René Rachou, Fundação Oswaldo Cruz, Belo Horizonte, MG. [2]. Programa de Pós-Graduação em Educação em Ciências: Química da Vida e da Saúde, Universidade Federal do Rio Grande do Sul, Porto Alegre, RS. [3]. Laboratório Nacional e Internacional de Referência em Taxonomia de Triatomíneos, Instituto Oswaldo Cruz, Fundação Oswaldo Cruz, Rio de Janeiro, RJ. [4]. Departamento de Ciências Biológicas, Universidade Federal de Ouro Preto, Ouro Preto, MG. [5]. Unidade de Tapes, Universidade Estadual do Rio Grande do Sul, Tapes, RS. [6]. Retired Professor, Free teaching in Entomology, Porto Alegre, RS.

\begin{abstract}
Introduction: Panstrongylus megistus is commonly found in wild environments of the State of Rio Grande do Sul, Brazil. The aim of this study was to characterize the network of refuges used by triatomine in a forest fragment of Porto Alegre and to identify Trypanosoma cruzi infection, associated hosts and the epidemiological importance of both hosts and triatomines. Methods: Techniques including the spool-and-line method and active searching (transects) were used to identify natural foci. Results: The food source for each triatomine was determined using the precipitin test, and the infection of marsupials was determined by xenodiagnosis. A total of 33 adults (domestic environment) and 27 nymphs (wild environment) of $P$. megistus were found in addition to 43 Didelphis albiventris specimens. The infection rates of triatomine adults, triatomine nymphs and opossums with $T$. cruzi I were $64 \%, 73 \%$ and $69 \%$, respectively. Birds, rodents and opossums were the main resources used by triatomine. Conclusions: This work presents the first characterization of a natural focus of P. megistus in Rio Grande do Sul. The natural characteristics of this focus and its implication in the transmission of T. cruzi are discussed.
\end{abstract}

Keywords: Panstrongylus megistus. Didelphis albiventris. Trypanosoma cruzi. Sylvatic foci. Rio Grande do Sul.

\section{INTRODUCTION}

Chagas disease was discovered in 1909 and remains one of the main neglected diseases in South America. In Brazil, it is estimated that approximately 1.9 million individuals are infected with Chagas disease, and an additional 23 million are at risk of acquiring it ${ }^{1}$. Due to the success of the Chagas Disease Control Program in 2006, Brazil was certified as free of disease transmissions by Triatoma infestans (Klug, 1834) and blood transfusion ${ }^{2}$. Among the main species of autochthonous triatomines of Brazil, Panstrongylus megistus (Burmeister, 1835) (Hemiptera, Reduviidae, Triatominae) is singularly known for its high capacity to adapt to domestic environments and wide distribution throughout the country, being present in 20 Federal Units ${ }^{3}$. Based on genetic and paleobiogeographic characteristics, several authors have demonstrated that the

\footnotetext{
Address to: Dr. José Eloy dos Santos Jr. CPqRR/FIOCRUZ. Av. Augusto de Lima 1715, Barro Preto, 30190-002 Belo Horizonte, MG, Brasil.

Phone: 5531 3349-7704; Fax: 5531 3295-3115

e-mail: santosjr_je@yahoo.com.br

Received 24 July 2013

Accepted 9 October 2013
}

States of Bahia (BA), Minas Gerais (MG), Pernambuco (PE), Rio de Janeiro (RJ) and São Paulo (SP) are probable areas of species endemism ${ }^{4-6}$. Currently, some of these states, particularly BA, MG, PE, SP and Alagoas, are areas of greatest epidemiological importance for P. megistus ${ }^{7}$.

The presence of this triatomine in natural environments represents possible sources of infestation and re-infestation of residences and also contributes to the maintenance of the sylvatic cycle of Trypanosoma cruzi ${ }^{3}$. Multiple authors have observed cohabitation of P. megistus and small mammals in other natural shelters since the beginning of the last century.

The first occurrence of $P$. megistus in natural environments was reported by Gomes ${ }^{8}$ in State of São Paulo (SP), citing the capture of a female trying to feed from her captor in the forest. In 1920, Oliveira ${ }^{9}$ presented evidence on possible relationships among the triatomine and T. cruzi natural reservoirs in Rio Grande do Sul (RS). However, he did not describe sylvatic foci. The first significant sylvatic focus was reported by Leal et al. ${ }^{10}$, who found numerous colonies in nests of opossums, rodents and cuícas in bromeliad clumps as well as holes in trees on an island in State of Santa Catarina (SC). In the same decade, Barretto et al. ${ }^{11}$ found a large number of $P$. megistus nymphs and adults in hollow trees, anfractuous agave clumps and roots of the fig tree Ficus euomphala in SP, recording a higher rate of infection in 
triatomines associated with opossums (39\%) than rodents (17\%). Work performed in the $1970 \mathrm{~s}$ by Forattini et al. ${ }^{6,12,13}$ showed P. megistus foci in hollow trees inhabited by bats, rodents, birds and, mainly, opossums as well as in epiphytic bromeliads, pine Cryptomeria sp. and palm Attalea sp. inhabited by opossums and rodents. In a study at Horto Forest (Rio de Janeiro-RJ) in 1982, Miles et al. ${ }^{14}$ found 12 nymphs infected by the parasite in a hollow tree inhabited by Didelphis marsupialis, and in 1985, SchlemperJr et al. ${ }^{15}$ detected an $84.5 \%$ rate of infection with $T$. cruzi in P. megistus associated with opossums and rodents in hollow trees and bromeliad clumps in SC. Grisard et al. ${ }^{16}$ found nymphs in hollow trees in the same state. The most recent work, performed by Santos-Jr et al. ${ }^{17}$ in the Bambuí, MG, municipality, reported the first finding of a $P$. megistus sylvatic colony in 69 years of research. This colony was discovered in the hollow of a large tree (Dimorphandra mollis Benth, popularly known as faveira).

Unlike the Northeast and Southeast Brazilian states, in RS, P. megistus is predominantly sylvatic and rarely colonizes the domestic environment. However, adult insect visits are common in dwellings in close proximity with sylvatic areas during the warmer months ${ }^{18}$. The first reports of Chagas disease vectors in RS were associated with the discovery of Triatoma rubrovaria (Blanchard, 1843) in 1911 and T. infestans in 1913 in the Pelotas municipality and surrounding areas ${ }^{19,20}$. Although vectors were detected during the early $20^{\text {th }}$ century, the first acute case was only described in 1939 at the boundary with Uruguay ${ }^{21}$. RS was one of the last states to be certified as free of Chagas disease transmission (2005) in Brazil ${ }^{22}$. Recently 11 species of triatomines have been recognized in the state; markedly, P. megistus, T. infestans (currently in residual foci) and T. rubrovaria have notable T. cruzi infection rates of $15 \%, 4 \%$ and $0.9 \%$, respectively ${ }^{22-27}$. In Porto Alegre, four triatomines species, T. circummaculata, T. oliverai (both rarely), T. infestans (last observed in 1950) and P. megistus (observed since 1931), have been reported and are found mainly in the southern municipality region ${ }^{28-30}$.

In addition to elucidating the trophic relationships between species, the identification of the various natural habitats shared by triatomines and their hosts allows for the characterization of potential risk areas related to T. cruzi transmission, leading to better Chagas disease control planning ${ }^{31}$. Various techniques have been used to identify these habitats, including light trapping, live-baited adhesive capture (Noireau trap) ${ }^{32}$, spooland-line methods ${ }^{33}$ and precipitin tests ${ }^{34}$.

This study aimed to characterize the network of refuges used by $P$. megistus in an ombrophilous dense forest fragment of Porto Alegre with an emphasis on T. cruzi infection, associated hosts and the epidemiological importance of both hosts and triatomines for the municipality.

\section{METHODS}

The municipality of Porto Alegre, the largest City of Rio Grande do Sul, Brazil, is situated at $100 \mathrm{~km}$ from the Atlantic Ocean and has a humid subtropical climate. Samples were collected in an ombrophilous dense forest fragment $\left(30^{\circ} 12^{\prime} 05^{\prime \prime} \mathrm{S}\right.$, $51^{\circ} 12^{\prime} 43^{\prime}$ W, $50 \mathrm{~m}$ ) of approximately 14 ha in the Ponta Grossa neighborhood, located in the Guaíba lake basin (Figure 1A, 1B, 1C and 1D). This region is formed by three forest areas: Alto Uruguay Subtropical Forest, Pines Forest and Atlantic Slope Rain Forest ${ }^{35}$. The inclusion or proximity of forests in urban areas make this region vulnerable to environmental changes.

Specimens were collected between October 2005 and September 2006. Four residences near the $10 \mathrm{~m}$ from the forest were investigated monthly for the presence of triatomines. Searches using flashlights and tweezers were performed in each domiciliary environment, and a light trap was installed (mercury lamp focused on a white wall) at a frequency of three nights per month. In the peridomiciliary, two doghouses, one pigsty, one hennery, firewood, tiles and two barns were searched. In the intradomiciliary, all rooms were investigated. In the sylvatic environment, marsupial refuges were investigated using transect and spool-and-line methods. Transects were traversed from north to south in the studied area, inspecting shelters up to $5 \mathrm{~m}$ away from the stipulated line. For the spool-and-line search, 20 wood traps $(25 \times 25 \times 40 \mathrm{~cm})$ were installed for capturing opossums (Figure 1E). The traps were baited with banana for two consecutive nights/month. At each capturing point, a mixture of codfish liver oil (Scott Emulsion ${ }^{\mathrm{TM}}$ ), papaya, banana and water was spread to attract marsupials. Captured opossums were subjected to xenodiagnosis ( 7 nymphs of T. infestans/20min), marked and equipped with spool-andline (IBAMA: 02023.002615/05-25). The design of these spool devices was adapted from that of Miles ${ }^{33}$; each device consisted of a cylindrical plastic pot with a screw cap $(4 \times 7 \mathrm{~cm})$ and a central axis (total weight: $54 \mathrm{~g}$ ). A yellow or orange colored $914 \mathrm{~m}$ polypropylene line was used $\left(\operatorname{Kooban}^{\mathrm{TM}}\right)$. When refuges were found, they were manually examined, and the internal materials were collected (e.g., leaves and twigs) for screening in the laboratory. Noireau traps were installed in inaccessible location $\mathrm{s}^{32}$. The distance traversed by the opossums was verified by the difference in the spool-in-line weight after a night route. Refuges with nymphs, eggs and/or exuviae were considered $P$. megistus foci. Refuges with triatomines and/or opossums were characterized.

Fresh feces collected from triatomines for xenodiagnosis were submitted to parasitological examination (diluting in saline solution) to verify trypanosome infection under an optical microscope (400x). Xenodiagnosis was assessed at 15, 30 and 45 days after exposure. Triatomine feces were stored on sterile filter paper (air dried and stored at $-20^{\circ} \mathrm{C}$ ) for the molecular characterization of T. cruzi (positive samples) and food source analyses (all samples). T. cruzi samples were identified by the presence of a nontranscribed spacer of the mini-exon gene. For deoxyribonucleic acid (DNA) extraction, round pieces of filter paper $(6 \mathrm{~mm})$ containing feces were boiled with $50 \mu \mathrm{L}$ of ultra-pure distilled water $\left(\mathrm{Gibco}^{\mathrm{TM}}\right)$ for $10 \mathrm{~min}^{36}$. The polymerase chain reaction (PCR) amplification and reaction conditions were performed according to the protocol of Souto et al. ${ }^{37}$, which used the following pooled primers: TC (5' - CCC CCC TCC CAG GCC ACA CTG), TCI (5' - GTG TCC GCC ACC TCC TTC GGG CC) and TCII (5' - CCT GCA GGC ACA CGT GTG TGT G). Amplification products were subjected to polyacrylamide gel $(8 \%)$ electrophoresis and observed by silver staining. Parasites were classified according to the procedures of Anonymous ${ }^{38}$ and Zingales et al. ${ }^{39}$. 

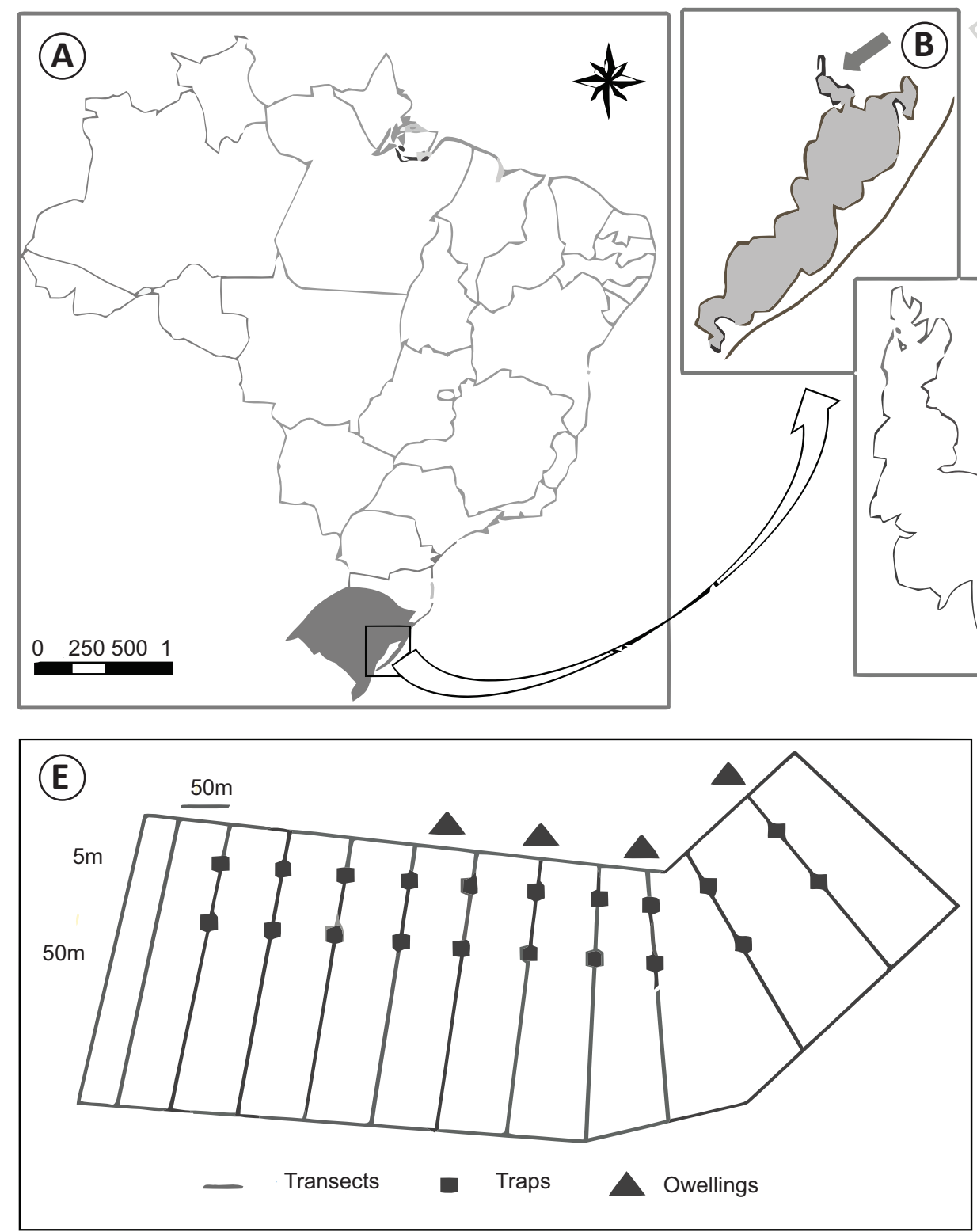

(B)
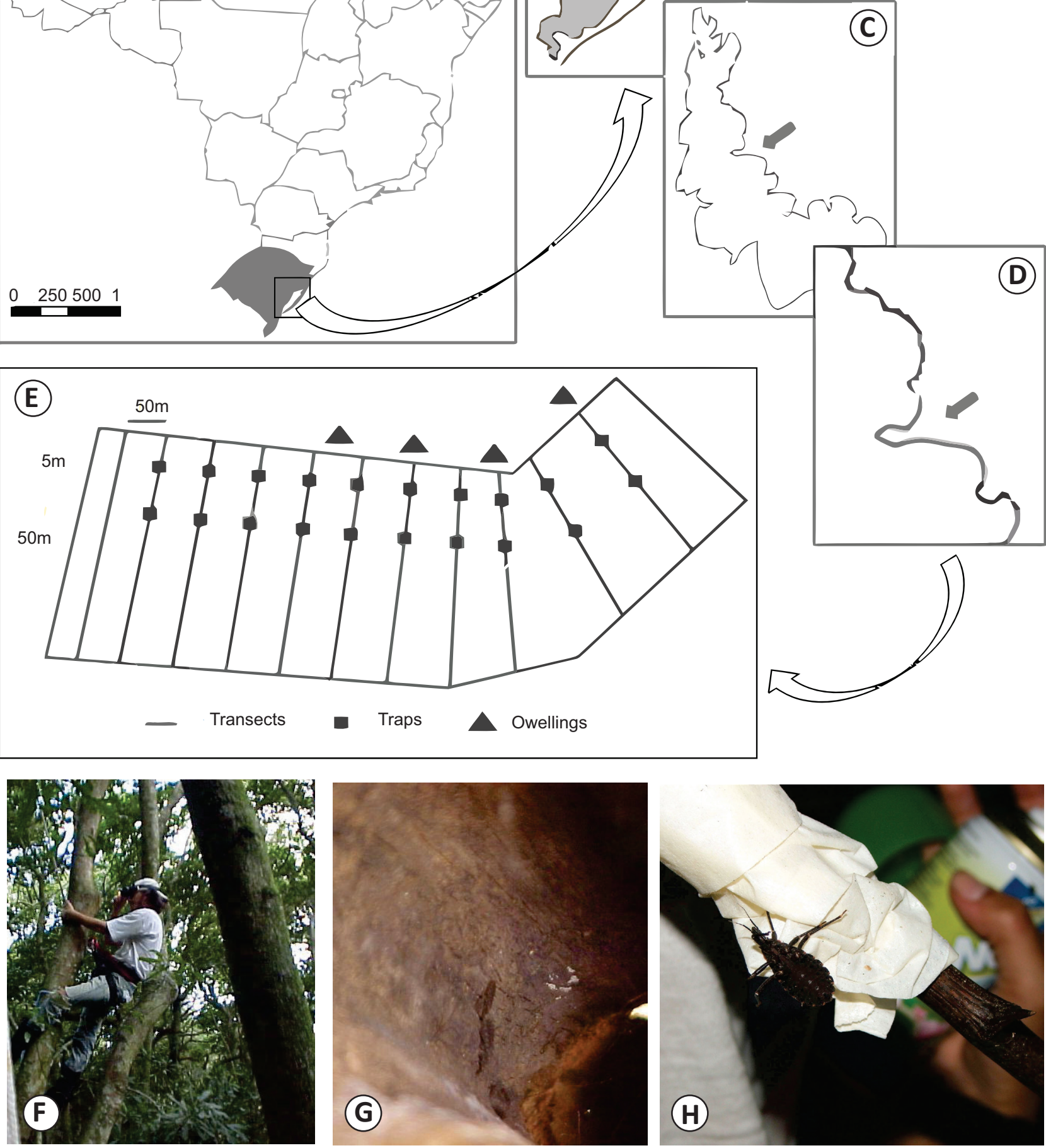

FIGURE 1 - Location of studied area: A: Brazil (arrow indicating the Figure 1B); B: Region of Patos lagoon and surroundings (arrow: Guaíba lake basin); C: Ponta Grossa neighborhood (arrow); D: Study area (arrow); E: Croquis drawing of the study area showing the opossum traps, transects and investigated dwellings; F: Investigation of a hollow tree with the aid of ropes; G: Panstrongylus megistus found inside the hollow; H: Nymph (N5) captured by adhesive tape. 
Food sources were determined by the precipitin test according to the methods of Lorosa et al. ${ }^{40}$. Anti-sera from the following species were used: armadillo, bird, cat, dog, horse, lizard, opossum, ox, pig and human. Statistical analyses were performed using an one-way ANOVA and the post-hoc Tukey test for the evaluation of technique efficacy (transects and spool-and-line). The sex ratio of infection by T. cruzi in the reservoirs was evaluated using the chi-square test with BioStat 4.0 software.

\section{RESULTS}

There were no colonies found inside residences or in peridomiciliary areas, and no triatomines were obtained using light traps. Peridomiciliary inspections revealed only the presence of adult insects, which were found on outside walls of residences visited between November 2005 and February 2006. The largest $P$. megistus captures occurred in December (Figure 2). Among the 33 triatomines collected, corresponding to $26(79 \%)$ males and $7(21 \%)$ females, 28 were analyzed, and $18(64 \%)$ were infected with T. cruzi. Molecular analysis characterized the parasites as $T$. cruzi I.

A total of 27 nymphs were collected: 26 (96\%) were analyzed and 19 (73\%) were infected. Different instars of P. megistus were found among the nymph samples at different times of the year: $26 \%$ were $2^{\text {nd }}$ instars ( 7 of 27$), 44 \%$ were $3^{\text {rd }}$ (12 of 27$), 4 \%$ were $4^{\text {th }}(1$ of 27$)$ and $26 \%$ were $5^{\text {th }}$ (7 of 27$)$. However, $4^{\text {th }}$ instars were only observed in March (Figure 3). All negative nymphs were found in the same refuges (dead tree hollow). Triatomine nymphs, eggs and/or exuviae were found only in tree refuges between 10 and $205 \mathrm{~m}$ from the forest fragment edge near the residences (Figure 1F, 1G and 1H).

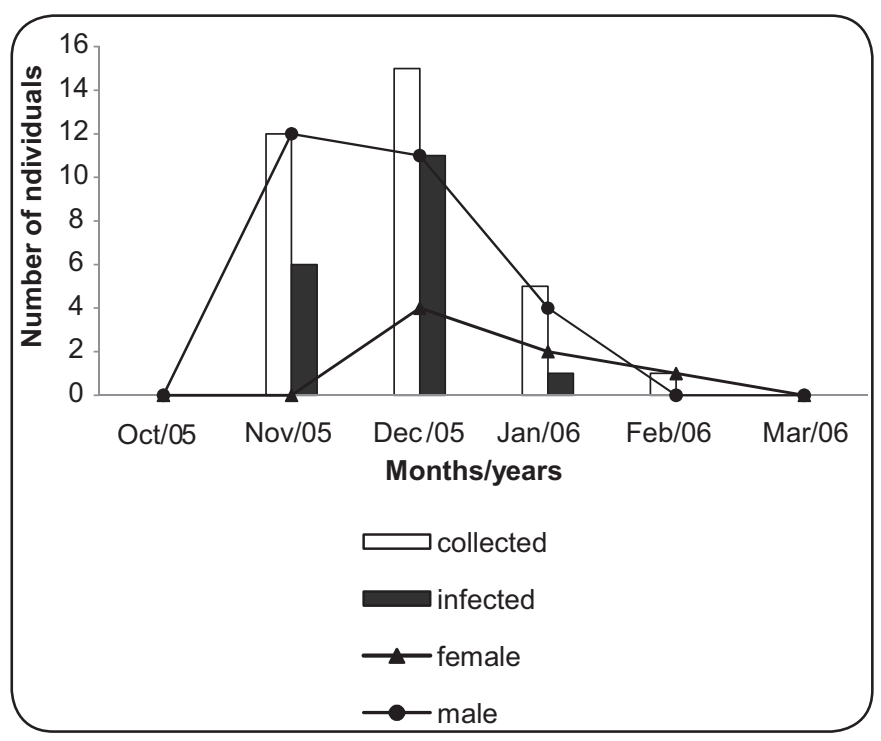

FIGURE 2 - Capture of Panstrongylus megistus adults throughout the months (October 2005 to March 2006) showing the number of infected individuals and the sex ratio of specimens from Porto Alegre, State of Rio Grande do Sul, Brazil.

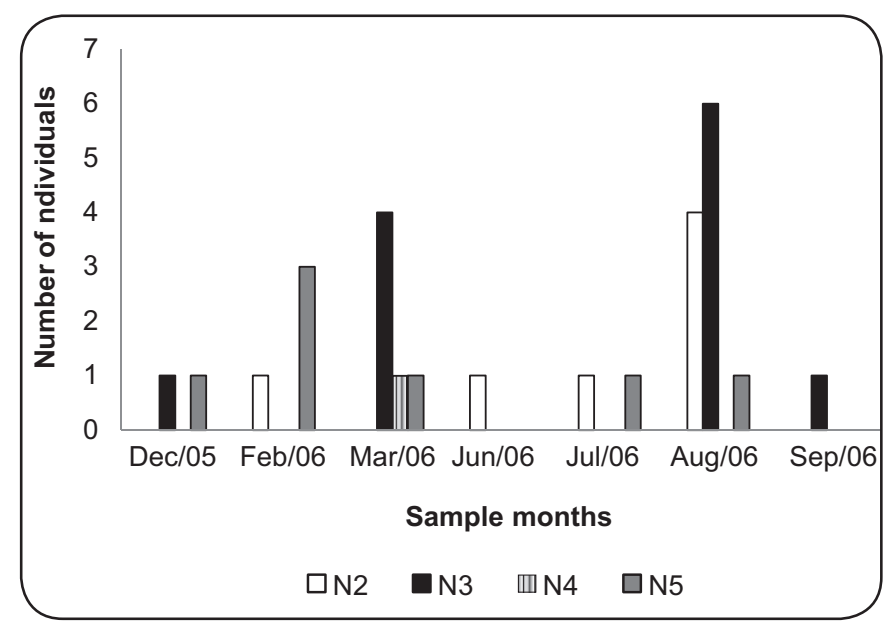

FIGURE 3 - Initial instars of Panstrongylus megistus (N2 to N5: $2^{\text {nd }}$ to $5^{\text {th }}$ instar) captured in the sylvatic environment in Porto Alegre, State of Rio Grande do Sul, Brazil. N: Nymph.

The Noireau traps captured two P. megistus nymphs $\left(3^{\text {rd }}\right.$ and $5^{\text {th }}$ instars) in opossum nests. The only adult triatomine obtained in this environment was a female found among the branches of a tree (in February 2006) (Table 1). Using the transect method, 33 refuges were found, of which 18\% (6 of 33) demonstrated the presence of $P$. megistus. Utilizing the spool-and-line method (with 27 opossums), 28 refuges were found, and this triatomine was present in $14 \%$ ( 4 of 28 ). There were no significant differences $(p>0.05)$ between the sampling methods. However, the spool-and-line method allowed for a better understanding of the shelters used by marsupials. A total of 61 refuges were observed and classified into five categories: $10(16 \%)$ rock shelters, $10(16 \%)$ dead trees, 11 (18\%) ground shelters, $13(22 \%)$ roots and $17(28 \%)$ live trees. Among the examined trees, seven species revealed a high number of refuges for $P$. megistus and D. albiventris, including Casearia sylvestris (chá-de-bugre), Coussapoa microcarpa (figueira-mata-pau), Ficus organensis (figueira-de-folha-miúda), Myrsine guianensis (capororoca), Diospyrus inconstans (maria-preta), Luehea divaricata (açoita-cavalo) and Trichilia elegans (pau-deervilha). The spool-and-line results indicated that triatomine foci occur between 5 and $893 \mathrm{~m}$ from the animal capture/release location. The opossum demonstrated a wide distribution in the area. In six refuges (four hollow trees and two rock shelters), only opossum nests were found (no triatomines foci) between $8 \mathrm{~m}$ and $259 \mathrm{~m}$ from the closest residences, representing a potential focus of $P$. megistus. A total of 462 traps were installed per night, resulting in 98 captures and recaptures of 43 different D. albiventris. Among these animals, 39 (91\%) were analyzed (26 males and 13 females), and 27 (69\%) were infected with T. cruzi. There was no significant difference $(\mathrm{p}>0.05)$ between the sexes that were caught. The parasites isolated from nymphs and opossums were characterized as T. cruzi I. Opossum characteristics, such as semi-nomadic habits, the use of the same nest by different individuals and two females sleeping together in a hollow tree, were observed in field specimens. 
TABLE 1 - Characteristics of hollows found in the sylvatic environment (October 2005 to September 2006) showing the different stages of Panstrongylus megistus, Trypanosoma cruzi infection and associated food sources in Porto Alegre, State of Rio Grande do Sul, Brazil.

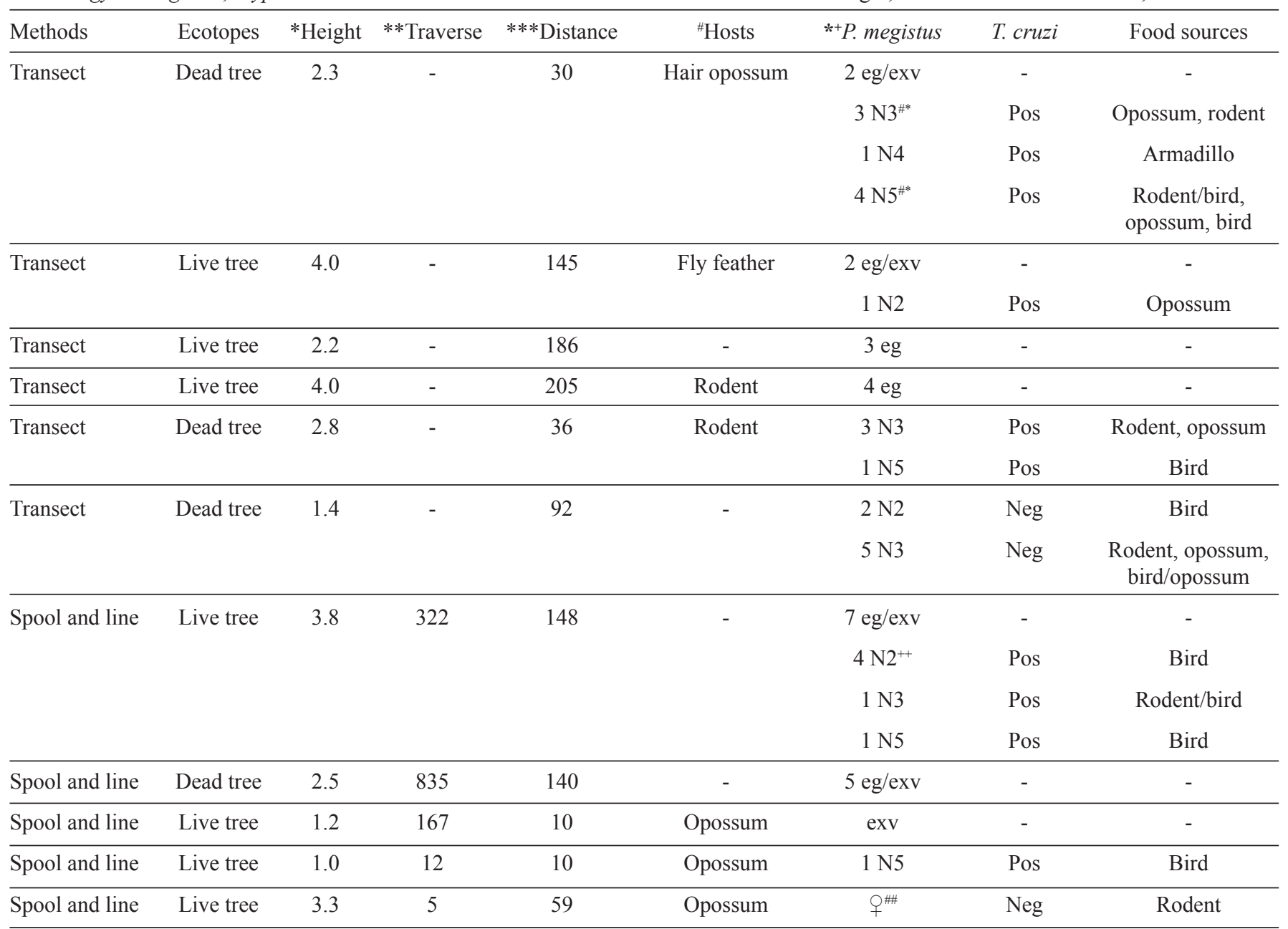

P. megistus: Panstrongylus megistus; T. cruzi: Trypanosoma cruzi. *height of hollows from the ground (m); **distance between the point of capture/release and opossums found $(\mathrm{m})$; ***distance between the hollows and nearest residence (m); "hosts found in hollows or traces observed; +two female opossums; ${ }^{*}+$ foci found: instars bugs found in the hollows, N2 to N5: nymphs of $2^{\text {nd }}$ to $5^{\text {th }}$ instar; eg: eggs hatched; exv: exuviae; ${ }^{\# *}$ one individual caught with Noireau traps; ${ }^{++}$one individual was not examined for T. cruzi and food source; ${ }^{\#}$ female found in the tree; Pos: (positive) and Neg (negative) for T. cruzi infection.

The precipitin test was conducted in 26 P. megistus nymphs and 29 adult insects. The nymphs were associated with four different hosts (bird, rodent, opossum and armadillo) in a manner that indicating that $88 \%$ used only one feeding source and $12 \%$ used two feeding sources. The adults were related to seven hosts (bird, rodent, opossum, armadillo, cat, dog and lizard) such that $77 \%$ used one food source, $20 \%$ used two hosts and only one (3\%) individual used three different host species. The bird, rodent and opossum showed the highest frequency of serving as hosts in both environments (sylvatic and peridomiciliar). There were no positive reactions for human blood (Table 2).

\section{DISCUSSION}

This paper reports the first discovery of a P. megistus sylvatic focus in RS. The occurrence of triatomines in residences during the warmer months was reported in Porto Alegre ${ }^{25,29}$, with males being more frequently present ${ }^{28}$. Even with the presence of early instar nymphs throughout the year, as observed in natural ecotopes, P. megistus showed only an annual life cycle, with adults emerging in the last months of spring. This feature is likely attributed to a prolongation of the $5^{\text {th }}$ instar due to low mobility and decreased hematophagism in the cold of winter. With the nearing of summer, there is an increased activity of individuals followed by a rise in the search for food, thereby leading to the dispersion of adult triatomines ${ }^{41,42}$. Although domestic $P$. megistus colonies were not found in the evaluated houses, the proximity of natural foci to residences could facilitate triatomine infestation ${ }^{15}$.

Although intradomiciliary triatomine foci were not found, the Programa de Controle da Doença de Chagas (PCDCh) has maintained continuous epidemiological surveillance. 
TABLE 2 - Frequency of the hosts associated with sylvatic and domestic Panstrongylus megistus in Porto Alegre, Rio Grande do Sukl, Brazil, as demonstrated by the reaction of precipitin.

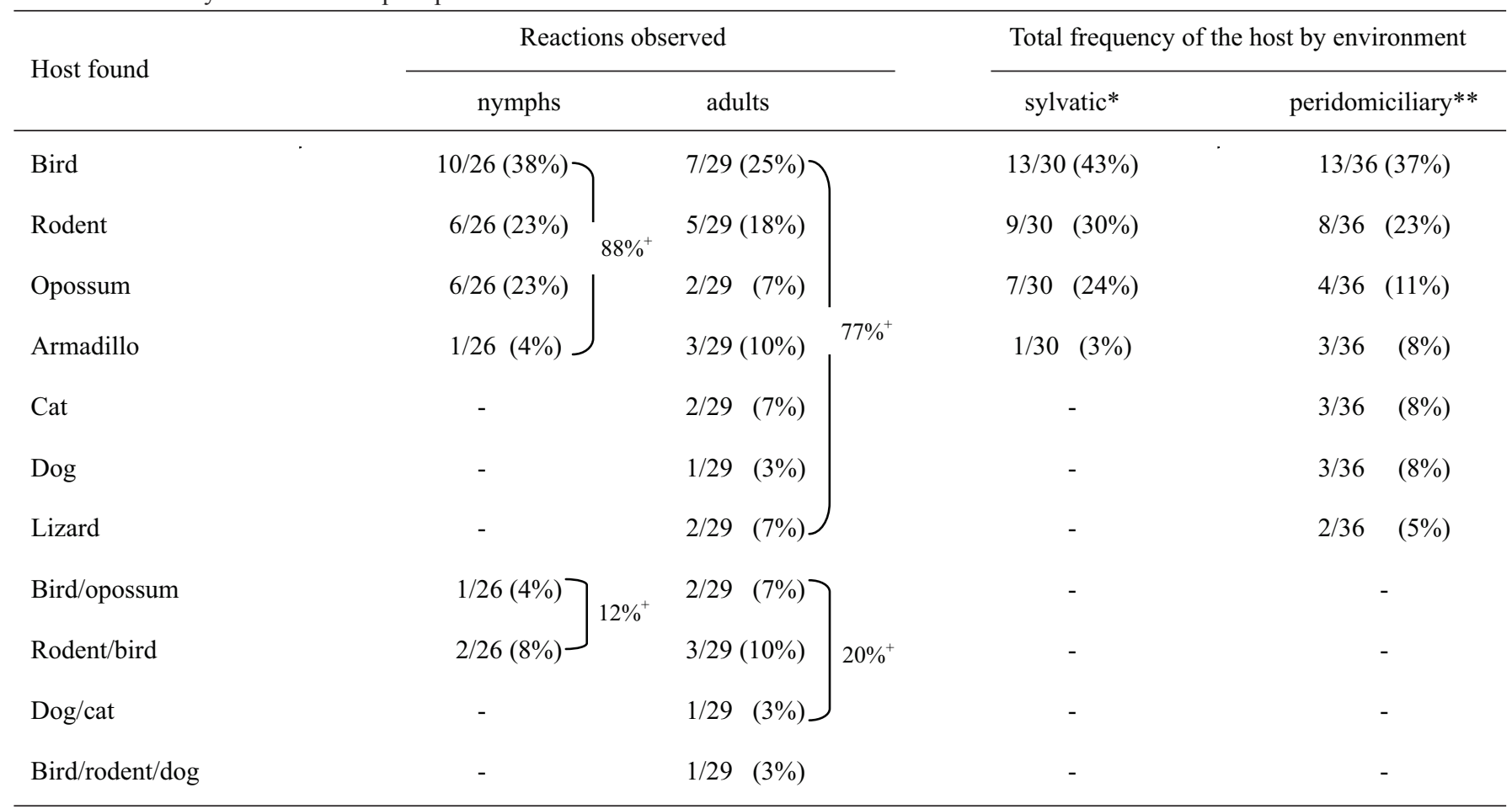

${ }^{*}$ nymphs and one female found in the natural environment; $* *$ only adults; ${ }^{+}$frequency $(\%)$ of one or two feeding sources identified.

The few studies performed in recent years have reported that only adults of $P$. megistus have been found in homes. Currently, the PCDCh has four PITs (Ponto de Informação de Triatomineos) in various parts of the city and advises residents regarding the presence of triatomines in houses near natural areas, the cleaning of peridomiciliary environments (avoiding potential foci) and the installation of screen doors and windows ${ }^{43}$.

In Bambuí State of Minas Gerais, Santos Jr et al. ${ }^{17}$ demonstrated that even with a low rate of infestation in sylvatic habitats, the colonization of domiciliary environments has been extensive during the last three decades. The presence of triatomines in sylvatic or, occasionally, domiciliary environments threatens to interrupt the progress of disease control measures in many areas given the focus of control programs on resident species ${ }^{44}$. These programs should implement new strategies to prevent human-vector contact using materials impregnated with insecticide, such as curtains and mosquito netting, and create alternatives for the proper management of the environment and maintenance of peridomiciliary areas ${ }^{45}$.

The lack of housing foci found in this work corroborates data from classic publications reporting that populations of the species in southern areas have a lower tendency to occupy artificial environments ${ }^{6,46,47}$. In an evaluation of populations in the States of Bahia, Minas Gerais and Santa Catarina, Barbosa et al. ${ }^{48}$ observed that the occupation of artificial environments may be related to a greater efficiency in resource utilization, presenting a demographic cline where the lowest fitness was observed in SC. Additionally, genetic and paleogeographic studies have demonstrated that the most recent geological events may have acted differently on the various $P$. megistus populations, leading to the observed behavioral differences in these species ${ }^{49}$.

According to Forattini ${ }^{6}$, P. megistus have a less invasive tendency of artificial ecotopes in more humid climates with rainy winters and larger preserved natural areas. Aragão ${ }^{46}$ showed that humidity followed by lower temperatures produces a greater wet surface permanence in residences, making such habitats unsuitable for these triatomines. However, the presence of $P$. megistus in artificial habitats in the States of Santa Catarina and Paraná demonstrates the species' ability to colonize this environment in the southern region of the country, even at a low intensity ${ }^{50,51}$. In the State of Rio Grande do Sul, the first domiciliary species focus was described by Di Primio ${ }^{30}$ in the municipality of Viamão. Here, colonies of the species were occasionally found in artificial environments, maintaining its sylvatic characteristics. According to Bedin et al. ${ }^{22}, 88 \%$ of the P. megistus found in RS between 1996 and 2008 occurred with residences, and $96 \%$ of these were adults.

Although found in different types of habitats, P. megistus demonstrates a preference for arboreal habitats ${ }^{11,13,18}$. This preferred ecotope provides an opportunity for greater contact between this triatomine and various species of rodents, marsupials and birds ${ }^{31}$. According to Barretto et al. ${ }^{12}$, sylvatic colonies of $P$. megistus may have a high rate of infection by 
T. cruzi, especially when associated with Didelphis sp. The presence of nymphs in the reservoir nests implies a significant circulation of the parasite between vector and host, as observed in this present study in which most of the sylvatic colonies showed $T$. cruzi infection. The omnivorous habit of opossums allows for the ingestion of insects as a nutritional alternative ${ }^{52}$. This insectivorous diet may act as an important route of T. cruzi infection when associated with the triatomines present in their burrows ${ }^{53}$, potentiated by semi-nomadic habits that enhance the possibility of encountering this vector in the natural environment ${ }^{54}$. T. cruzi oral infection experiments demonstrated a high infectivity toward marsupials, especially those that ingested infected triatomines ${ }^{54,55}$.

According to Patterson et al. ${ }^{44}$, high infection rates might be an indicator of close proximity to reservoir hosts and high susceptibility to $T$. cruzi. In this paper, infection rates were higher than in other studies conducted in RS $\left(41 \%{ }^{40}\right.$ and $50 \%{ }^{18}$ for $P$. megistus and $18 \%{ }^{56}$ for D. albiventris). However, the results presented herein are in agreement with studies in other states $\left(39-85 \%\right.$ for P. megistus ${ }^{12,14}$ and $11-91.7 \%$ for D. albiventris ${ }^{57-59}$ ). The parasite characterization performed here allowed us to observe the involvement of $D$. albiventris and $P$. megistus in the maintenance of the T. cruzi sylvatic cycle. In contrast, Fernandes et al. ${ }^{56}$ demonstrated that although P. megistus showed only Trypanosoma cruzi $\mathrm{Z} 1\left(\mathrm{TCI}^{39}\right)$ in Porto Alegre, D. albiventris was found with Trypanosoma cruzi Z2 $\left(\mathrm{TCII}^{39}\right)$, suggesting that the involvement of these marsupials in domestic cycles may serve as a carrier mechanism for this group in the natural environment.

The evaluation of food sources revealed that the main resources used by adult and nymph triatomines were birds, rodents and opossums. These three animals may use the same shelters in trees, as observed by Barretto et al. ${ }^{11,60}$. Although not analyzed in this study, the association of rodents with infected triatomine colonies highlights their epidemiological potential as loci, as rodents are considered potential reservoirs in the T. cruzi sylvatic cycle. Birds, although refractory to parasites, enable the maintenance of colonies and can act as population growth vectors, thereby increasing the risk of disease transmission, especially if the triatomines had previous contact with an infected mammal ${ }^{61}$. In an analysis of populations in the State of Minas Gerais Midwest, Villela et al..$^{62}$ also found a higher level of blood feeding on birds in triatomines captured in peridomiciliary environments; however, the majority (90.4\%) of individual triatomines fed on only one source (bird and others species). The same authors showed that $44 \%$ of infected bugs had this source.

The adults showed three food sources that were lacking nymphs: cats, dogs and lizards. Cats were found living only in the woods due to the hostility of the local people; thus, dogs were the only domestic animals used as a food source by triatomines. The number of food sources indicated the eclecticism of P. megistus ${ }^{40,63}$.

The presence of anti-armadillo serum in a nymph found in a hollow tree suggests a considerable mobility of these triatomines in the natural environment. Forattini et al ${ }^{64}$ observed the mobility of $4^{\text {th }}$ and $5^{\text {th }}$ instar Triatoma arthurneivai nymphs, which walked up to $10 \mathrm{~m}$ between the studied habitats. A similar behavior was indicated for $P$. megistus ${ }^{13}$. The lower occurrence of dogs and absence of other animals, such as pigs, cattle and humans, resulted in a low rate of infestation, confirmed by the absence of peridomestic colonies and a similarity of food sources between adults and nymphs.

The forest fragment analyzed here represents the typical arboreal species in the granite hills of Porto Alegre and, considering its natural conditions, contributes to the maintenance of the sylvatic characteristics of P. megistus. Thus, based on the data presented in this study, it is suggested that sites with similar characteristics in the city can present similar rates of infection. Thus, sylvatic areas at greatest risk of urban effects tend to connect humans and domestic animals to the sylvatic cycle of the parasite. Despite the absence of colonization, the high number of infected opossums and triatomines demonstrates the potential risk of $T$. cruzi transmission in the municipality, which suggests the importance of continued epidemiological surveillance and management strategies in environmentally important areas of the native city.

\section{ACKNOWLEDGMENTS}

We are grateful to MSc. Christiane Santos Matos and Dra. Liléia Diotaiuti for the technical assistance in this manuscript, Carlos Eduardo Velho de Carvalho by assistance of samples, Fernanda Mello and Getúlio Dornelles Souza by support of Programa de Controle de Doença de Chagas.

\section{CONFLICT OF INTEREST}

The authors declare that there is no conflict of interest.

\section{FINANCIAL SUPPORT}

Conselho Nacional de Pesquisa e Desenvolvimento Tecnológico (CNPq).

\section{REFERENCES}

1. Rassi Jr A, Rassi A, Marin-Neto JA. Chagas disease. Lancet 2010; 375:1388-1402.

2. Dias JCP. Doença de Chagas: sucessos e desafios. Cad Saude Publica 2006; 22:2020-2021.

3. Carcavallo RU, Franca Rodríguez ME, Salvatella R, Curto de Casas SI, Sherlock IS, Galvão C, et al. Hábitats e fauna relacionada. In: Carcavallo RU, Galíndez Girón I, Jurberg J, Lent H, orgs. Atlas dos Vetores da Doença de Chagas nas Américas. Vol. II. Rio de Janeiro: Fiocruz; 1998. p. 561-619.

4. Barbosa SE, Dujardin JP, Soares RP, Pires HH, Margonari C, Romanha $\mathrm{AJ}$, et al. Interpopulation variability among Panstrongylus megistus (Hemiptera: Reduviidae) from Brazil. J Med Entomol 2003; 40:411-420.

5. Forattini OP. Biogeografia, origem e distribuição da domiciliação de triatomíneos no Brasil. Rev Saude Publica 1980; 14:265-299.

6. Forattini OP, Ferreira AO, Silva EOR, Rabello EX. Aspectos ecológicos da tripanossomose americana XII - Variação regional da tendência de 
Panstrongylus megistus à domiciliação. Rev Saude Publica 1978; 12:209233.

7. Diotaiuti L. Ecologia. In: Diotaiuti L, Oliveira MA, Santos JP, orgs. Triatomíneos. Belo Horizonte: Centro de Pesquisa René Rachou; 2008. p. 112-128.

8. Gomes JF. Triatomas e molestia de Chagas no Estado de São Paulo. I Congresso Med Paulista 1916; 2:193-214.

9. Oliveira G. Isolamento do Trypanosoma cruzi e outras noções concernentes à moléstia de Chagas do Rio Grande do Sul. Brasil Med 1920; 34:142-143.

10. Leal H, Ferreira Neto JA, Martins CM. Dados ecológicos sobre triatomíneos silvestres na ilha de Santa Catarina, Brasil. Rev Inst Med Trop São Paulo 1961; 3:213-220.

11. Barretto MP, Siqueira AF, Pedreira de Freitas JL. Estudo sobre reservatórios e vetores do Trypanosoma cruzi II - Encontro do Panstrongylus megistus em ecótopos silvestres no Estado de São Paulo (Hemiptera, Reduviidae). Rev Inst de Med Trop 1964; 6:56-63.

12. Forattini OP, Ferreira OA, Silva EOR, Rabello EX. Aspectos ecológicos da tripanossomose americana. VIII - Domiciliação de Panstrongylus megistus e sua presença extradomiciliar. Rev Saude Publica 1977; 11: 73-86.

13. Forattini OP, Rabello EX, Castanho MLS, Pattoli DGB. Aspectos ecológicos da tripanossomose americana I - Observações sobre Panstrongylus megistus e suas relações com focos naturais da infecção em área urbana da cidade de São Paulo, Brasil. Rev Saude Publica 1970; 4:19-30.

14. Miles M, Souza AAA, Póvoa MM. O ecótopo de Panstrongylus megistus (Hemiptera, Reduviidae) na floresta do Horto (Rio de Janeiro). Rev Bras Biol 1982; 42:31-35.

15. Schlemper Jr BR, Steindel M, Gargioni R, Farias CJM, Oliveira R, Trianon JAX. Reservatórios e vetores silvestres do Trypanosoma cruzi e suas relações com o domicílio humano na Ilha de Santa Catarina. Arq Cat Med 1985; 14:91-96.

16. Grisard EC, Carvalho-Pinto CJ, Scholz AF, Toma HK, Schlemper BR $\mathrm{Jr}$, Steindel M. Trypanosoma cruzi infection in Didelphis marsupialis in Santa Catarina and Arvoredo Islands, Southern Brazil. Mem Inst Oswaldo Cruz 2000; 95:795-800.

17. Santos Júnior JE, Diotaiuti L, Dias JC. First report of Panstrongylus megistus sylvatic focus in municipality of Bambuí, state of Minas Gerais, Brazil. Mem Inst Oswaldo Cruz 2011; 106:510-513.

18. Ruas Neto AL, Krug L. Epidemiologia da doença de Chagas no Rio Grande do Sul: A distribuição vetorial. Bol Soc Zool Uruguay 1995; 9:20-32.

19. Neiva A, Pinto C. Representantes dos gêneros "Triatoma Lap., Rhodnius Stal" encontrados no Brasil Central e Sul; observações biológicas e descrição de uma nova espécie. Brasil Med 1923; 37:84-86.

20. Neiva A, Pinto C, Lent H. Notas sobre triatomideos do Rio Grande do Sul e descrição de uma nova espécie. Mem Inst Oswaldo Cruz 1939; 34 : 607-610.

21. Talice RV. Sobre el primero caso de enfermidad de Chagas comprobado em El Estado de Rio Grande Del Sur (Brasil). Arch Urug Med Cirurg y Espec 1939; 14:558-566.

22. Bedin C, Mello F, Wilhelms TS, Torres MA, Estima C, Ferreira CF, et al. Vigilância ambiental: doença de Chagas no Rio Grande do Sul. Bol Epidemiol 2009; 11:1-8.

23. Ruas-Neto AL, Corseuil E. Hábitos, distribuição geográfica e potencialidade dos triatomíneos rupestres como vetores da doença de Chagas no Rio Grande do Sul, Brasil. Entomol Vect 2002; 9:231-249.

24. Di Primio R. Atual distribuição geográfica dos triatomíneos e seus índices de infecção no Rio Grande do Sul. An Fac Med de Porto Alegre 1957; 17:17-37.

25. Di Primio R. Contribuição para o estudo do Panstrongylus megistus no Rio Grande do Sul. An Fac Med de Porto Alegre 1957; 36-40.

26. Di Primio R. Triatomíneos e seus índices de infecção pelo Trypanosoma cruzi no Rio Grande do Sul. An Fac Med de Porto Alegre 1959; 21-35.
27. Di Primio R. Triatomíneos e seus índices de infecção no Rio Grande do Sul. An Fac Med de Porto Alegre 1972; 32:9-13.

28. Souza GD. Vigilância de triatomíneos e grau de infecção natural, no município de Porto Alegre, RS. In: XX Congresso Brasileiro de Entomologia; Gramado, Rio Grande do Sul, Brasil: 2004. p. 466.

29. Di Primio R. Triatomíneos de Porto Alegre. An Fac Med de Porto Alegre 1963; 23:22-25.

30. Di Primio R. Sobre a presença do Neotriatoma circummaculata em Porto Alegre - outras constatações. An Fac Med de Porto Alegre 1966; 26:7377.

31. Moreno AR, Carcavallo RU. Enfoque ecológico da epidemiologia da doença de Chagas. In: Carcavallo RU, Galíndez Girón I, Jurberg J, Lent H. orgs. Atlas dos Vetores da Doença de Chagas nas Américas. Vol III. Rio de janeiro: Fiocruz; 1999. p. 981-1016.

32. Noireau F, Flores R, Vargas F. Trapping sylvatic Triatominae (Reduviidae) in hollow trees. Trans R Soc Trop Med Hyg 1999; 93:13-14.

33. Miles MA. A simple method of tracking mammals and locating triatomine vectors of Trypanosoma cruzi in Amazonian forest. Am J Trop Med Hyg 1976; 25:671-674.

34. Siqueira AF. Estudos sobre a reação de preciptina aplicados a identificação de sangue ingerido por triatomíneos. Rev Inst Med Trop São Paulo 1960; 2:41-53.

35. Führo D, Vargas D, Larocca J. Levantamento florístico das espécies herbáceas, arbustivas e lianas da floresta de encosta da ponta do cego, reserva biológica do Lami (RBL), Porto Alegre, Rio Grande do Sul, Brasil. Pesq Bot 2005; 56:239-256.

36. Machado EMM, Alvarenga NJ, Romanha AJ, Grisard EC. A simplified method for sample collection and DNA isolation for Polymerase Chain Reaction detection of Trypanosoma rangeli and Trypanosoma cruzi in Triatominae vectors. Mem Inst Oswaldo Cruz 2000; 95:863-866.

37. Souto R, Fernandes O, Macedo A, Campbell D, Zingales B. Dna markers define two major phylogenetics linageages of Trypanosoma cruzi. Mol Biochem Parasitol 1996; 83:141-152.

38. Anonymous. Recommendations from a Satellite Meeting. Mem Inst Oswaldo Cruz 1999; 94 (supl I): 429-432.

39. Zingales B, Andrade SG, Briones MRS, Campbel DA, Chiari E, Fernandes $\mathrm{O}$, et al. A new consensus for Trypanosoma cruzi intraspecific nomenclature: second revision meeting recommends TcI to TcVI. Mem Ins Oswaldo Cruz 2009; 107:1051-1054.

40. Lorosa ES, Nunes IM, Vinhaes MC, Andrade RE, Jurberg J. Preferência alimentar de algumas espécies de triatomíneos capturados no Estado do Rio Grande do Sul, Brasil, com auxílio da técnica de preciptina e grau de infectividade. Entomol Vect 2000; 7:211-225.

41. Dias E, Dias JCP. Variações mensais da incidência das formas evolutivas do Triatoma infestans e do Panstrongylus megistus no município de Bambuí, Estado de Minas Gerais (IIa Nota: 1951 a 1964). Mem Inst Oswaldo Cruz 1968; 66:209-226.

42. Lehane MJ, McEven PK, Whiteker CJ, Schofield CJ. The role of temperature and nutricional status in flight initiation by Triatoma infestans. Acta Trop 1992; 52:27-38.

43. Coordenadoria Geral de Vigilância em Saúde (CGVS) da Prefeitura de Porto Alegre. Barbeiros/Doença de Chagas [Internet]. CGVS: Porto Alegre; [Cited 2013 September 26]. Available at: http://www2.portoalegre.rs.gov. br/cgvs/default.php?p_secao=137/.

44. Patterson JS, Barbosa SE, Feliciangeli MD. On the genus Panstrongylus Berg 1879: Evolution, ecology and epidemiological significance. Acta Tropica 2009; 110:187-199.

45. Guhl F, Pinto N, Aguilera G. Sylvatic triatominae: a new challenge in vector control transmission. Mem Inst Oswaldo Cruz 2009; 104 (supl I):71-75.

46. Aragão MB. Aspectos climáticos da doença de Chagas II - Área de ocorrência do Panstrongylus megistus (Burmeister, 1835). Rev Bras Malar 1961; 13:171-193.

47. Pessoa SB. Domiciliação dos triatomíneos e epidemiologia da doença de Chagas. Arq Hig Saude Publica 1962; 27:162-171. 
48. Barbosa SE, Soares RPP, Pires HHR, Diotaiuti L. Experimental evidence for a demographic cline in Panstrongylus megistus populations. Mem Inst Oswaldo Cruz 2001; 96:773-775.

49. Barbosa SE, Belisário CJ, Souza RCM, Paula AS, Linardi PM, Romanha $\mathrm{AJ}$, et al. Biogeography of brazilian populations of Panstrongylus megistus (Hemiptera, Reduviidae, Triatominae) based on molecular marker and paleo-vegetational data. Acta Trop 2006; 99:144-154.

50. Guilherme ALF, Lorosa ES, Costa AL, Pavanelli GC, Araújo SM. Panstrongylus megistus em ecótopos artificiais de ilhas do Alto Rio Paraná. Rev Soc Bras Med Trop 2001; 34:491-494.

51. Steindel M, Toma HK, Carvalho Pinto CJ, Grisard EC, Schlemper Jr BR. Colonização de ecótopos artificiais pelo Panstrongylus megistus na Ilha de Santa Catarina, Florianópolis, Santa Catarina, Brasil. Rev Inst Med Trop São Paulo 1994; 36:43-50.

52. Cáceres NC, Monteiro-Filho ELA. Food habits, home range and activity of Didelphis aurita (Mammalia, Marsupialia) in a Forest Fragment of Southern Brazil. Stud Neo F Envir 2001; 36:85-92.

53. Schweigmann NJ, Pietrokovsky S, Bottazzi V, Conti O, Bujas MA, Wisnivesky-Colli C. Estudio de la prevalencia de la infección por Trypanosoma cruzi en zarigüeyas (Didelphis albiventris) en Santiago del Estero, Argentina. Rev Pan Salud 1999; 6:371-377.

54. Schweigmann NJ, Pietrokovsky S, Bottazzi V, Conti O, Wisnivesky-Colli C. Interaction between Didelphis albiventris and Triatoma infestans in relation to Trypanosoma cruzi transmission. Mem Inst Oswaldo Cruz 1995; 90:679-682.

55. Ribeiro RD, Garcia TAR, Bonomo WC. Contribuição para o estudo dos mecanismos de transmissão do agente etiológico da doença de Chagas. Rev Saude Publica 1987; 21:51-54.

56. Fernandes CD, Murta SMF, Cerávolo IP, Krug LP, Vidigal PG, Steindel M, et al. Characterization of Trypanosoma cruzi Strains Isolated from Chronic Chagasic Patients, Triatomines and Opossums Naturally Infected from the State of Rio Grande do Sul, Brazil. Mem Inst Oswaldo Cruz 1997; 92: 343-351.

57. Fernandes AJ, Chiari E, Rodrigues RB, Dias JCP, Romanha AJ. The importance of the opossum (Didelphis albiventris) as a reservoir for Trypanosoma cruzi in Bambuí, Minas Gerais state. Mem Inst Oswaldo Cruz 1991; 86:81-85.

58. Fernandes O, Mangia RH, Lisboa CV, Pinho AP, Morel CM, Zingales B, et al. The complexity of the sylvatic cycle of Trypanosoma cruzi in Rio de Janeiro state (Brazil) revealed by the nontranscribed spacer of the miniexon gene. Parasitology 1999; 118:161-166.

59. Rodrigues BA, Mello GB. Contribuição ao estudo da tripanosomíase americana. Mem Inst Oswaldo Cruz 1942; 37:77-94.

60. Barretto MP, Ribeiro RD, Rocha GM. Estudos sobre reservatórios e vectores silvestres do Trypanosoma cruzi. LXIX: Inquérito preliminar sobre triatomíneos silvestres na região do Triângulo Mineiro, MG, Brasil. Rev Bras Biol 1978; 38:633-637.

61. Wisnivesky-Colli C, Ruiz AM, Ledesma O, Gürtler RE, Lauricella MA, Salomon DD, et al. Ecologia doméstica de la tripanosomiasis americana: Perfil alimentario del Triatoma infestans en un área rural de Santiago del Estero. Rev Soc Bras Med Trop 1987; 20:31-39.

62. Villela MM, Rodrigues VLCC, Casanova C, Dias JCP. Análise da fonte alimentar de Panstrongylus megistus (Hemiptera, Reduviidae, Triatominae) e sua atual importância como vetor do Trypanosoma cruzi, no Estado de Minas Gerais. Rev Soc Bras Med Trop 2010; 43:125-128.

63. Rodrigues VLCC, Ferraz Filho AN, Silva EOR, Lima VLC. Prevalência, índices de infecção e hábitos alimentares de triatomíneos capturados em uma área de vigilância epidemiológica. Rev Soc Bras Med Trop 1992; 25:183-190.

64. Forattini OP, Rabello EX, Pattoli DBG. Aspectos ecológicos da tripanossomose americana IV - Mobilidade de Triatoma arthurneivai em seus ecótopos naturais. Rev Saude Publica 1972; 6:183-187. 